\title{
Characterization and antioxidant ability of potential probiotic lactic acid bacteria in ogi liquor and lemon juice-ogi liquor
}

\author{
Titilayo Adenike Ajayeoba ${ }^{1}$ (D) $\cdot$ Oluwatosin Ademola ljabadeniyi ${ }^{1}$
}

Received: 23 November 2018 / Accepted: 21 March 2019/Published online: 1 April 2019

(C) Università degli studi di Milano 2019

\begin{abstract}
Purpose $O g i$ is an indigenous edible fermented cereal slurry but the steep liquor is usually wasted or administered as therapeutic to suppress certain illnesses. The combination of lemon juice and ogi steep liquor (OSL) is known to possess bioactive metabolites.

Method This study evaluated potential probiotic lactic acid bacteria (LAB) in different OSL (Zea mays, Sorghum bicolor, and Pennisetum glaucum L.) and lemon juice-ogi steep liquor (LJOSL) based on low pH, bile and lysozyme tolerances, hydrophobicity and auto-aggregation, antibiotic, cholesterol removal, exopolysaccharide production, $\beta$-galactosidase, and antimicrobial and hemolytic activities using standard methods. Presumptive LAB were sequenced and assayed for radical scavenging using 2,2-diphenyl-1-picrylhydrazyl (DPPH) and lipid peroxidation inhibitory (LPI) tests.

Results Presumptive LAB counts were higher in maize OSL ( $0 \mathrm{~h}: 5.09 \log$ CFU/ml) and combined cereal OSL ( $24-48 \mathrm{~h}: 7.65$ and $7.72 \log \mathrm{CFU} / \mathrm{ml}$ ) but decreased in all steep liquors at $72 \mathrm{~h}$, except in millet OSL (7.72 log CFU/ml). A total of $120 \mathrm{LAB}$ isolates were randomly selected. Based on $\mathrm{pH}$ and bile tolerances, 14 isolates were comparable to reference strains. All these isolates demonstrated probiotics properties except for three that did not show $\gamma$-hemolysis. Sequenced LAB isolates were identified as Lactobacillus plantarum, Lactobacillus fermentum, Pediococcus pentosaceus, and Weissella cibara. DPPH activities of LAB gradually increased during fermentation with the highest activity of DPPH (58.77\%) and LPI (57.94\%) activity in L. plantarum. Strong correlations were found between DPPH and LPI in all the selected isolates.

Conclusion The antioxidant property of probiotic LAB in OSL and LJOSL could contribute to its therapeutic nature.
\end{abstract}

Keywords Lactic acid bacteria $\cdot$ Probiotics $\cdot$ Lemon juice-ogi steep liquor $\cdot$ ogi steep liquor $\cdot$ Antioxidant

\section{Introduction}

In most of the African countries, traditional fermented cereal foods form an integral part of the human diet because it is readily available and affordable (Obinna-Echem et al. 2014). The fermentation of cereal depends on the biological activities of microorganisms, which convert organic substrates into more desirable substances that impact preferred taste, and

Electronic supplementary material The online version of this article (https://doi.org/10.1007/s13213-019-01469-4) contains supplementary material, which is available to authorized users.

Titilayo Adenike Ajayeoba

titilayoa@dut.ac.za

1 Department of Biotechnology and Food Technology, Durban University of Technology, Steve Biko Campus, Durban 4001, South Africa enhanced micronutrients. Some fermented beverages like kunu-zaki, burukutu, and ogi are a part of traditional and cultural values of Nigeria (Egwim et al. 2013).

Ogi is made from the fermentation of a variety of cereals but the resulting steep liquor is usually wasted. Ogi steep liquor (OSL) has bioactive compounds (Ojokoh 2011; Ajayeoba et al. 2016) which are traditionally believed to change gastrointestinal microbiota and suppress the growth of pathogens (Egwim et al. 2013). Lemon is known to possess medicinal properties. Lemon juice has been used in combination with other antimicrobial products such as honey and OSL for inhibiting microorganisms like Salmonella, Shigella, Escherichia coli, Listeria monocytogenes, and Staphylococcus aureus (Dhanavade et al. 2011; Ajayeoba et al. 2016).

The dominant microorganisms reported in OSL are represented by lactic acid bacteria (LAB) such as Lactobacillus spp., Corynebacterium spp., Leuconostoc, Lactococcus, Pediococcus, and Weissella (Ijabadeniyi 2007; Obinna- 
Echem et al. 2014; Okeke et al. 2015). The addition of lemon juice to OSL reduces its $\mathrm{pH}$ (Ajayeoba et al. 2016), thus creating an environment for the survival of potential probiotics. Sometimes, OSL and lemon are consumed in the raw form. Although it is believed that OSL can enhance the treatment of certain illnesses, a largely overlooked aspect of its consumption is the probiotic potentials of LAB and antioxidant activities. Therefore, this study intended to characterize the potential probiotic $\mathrm{LAB}$ occurring during the fermentation of OSL and lemon juice-ogi steep liquor, from a variety of cereal substrates, and determine the antioxidant activity of the isolates.

\section{Materials and methods}

\section{Sample collection}

White maize (Zea mays), white sorghum (Sorghum bicolor), and pearl millet (Pennisetum glaucum L.) were purchased from Igbona market, Osogbo, Nigeria, while lemon (Citrus limon) fruits were procured from Durban, South Africa. The reference strains Lactobacillus casei ATCC 393 and L. plantarum ATCC 8014, test strain Escherichia coli O157:H7, Listeria monocytogenes ATCC 7644, Staphylococcus aureus ATCC 29213, and Salmonella enterica ATCC 13076 were obtained from the Food Laboratory, Department of Biotechnology and Food Technology, Durban University of Technology, South Africa. The media, antibiotic discs, and chemicals used for the experiments were products of Oxoid (UK) and SigmaAldrich (USA).

\section{Preparation of OSL, LOSL, and isolation of LAB}

OSL and lemon juice-ogi steep liquor (LJOSL) were prepared by following the method described by Ajayeoba et al. (2016). Ogi samples were prepared in duplicates. A total of 64 liquor samples (white maize steep liquor, white sorghum steep liquor, millet steep liquor, combined cereals liquor, lemon juice-ogi steep liquor samples for each liquor) were prepared separately. After preparation, the ogi slurry of each processed cereal was allowed to settle for $30 \mathrm{~min}$ and $10 \mathrm{ml}$ was taken from each replicate $(0 \mathrm{~h})$. About $1 \mathrm{ml}$ of OSL was serially diluted, cultured into $9 \mathrm{ml}$ MRS (de Mann Rogosa Sharpe) broth, and incubated for $24 \mathrm{~h}$ at $35^{\circ} \mathrm{C}$. LAB were isolated by spread plating appropriate aliquots on MRS agar and incubating at $35{ }^{\circ} \mathrm{C}$ for $48 \mathrm{~h}$. The same procedure was repeated during fermentation of each liquor at $24 \mathrm{~h}, 48 \mathrm{~h}$, and $72 \mathrm{~h}$ respectively. Colonies that had morphologies similar to the LAB were randomly selected from the duplicates for tentative identification. Gram staining, catalase reaction, growth at different temperatures and at different $\mathrm{NaCl}$ concentrations, gas production from glucose, hydrolysis of arginine, and carbohydrate fermentation were studied. Potential isolates were sub-cultured and stored at $-80{ }^{\circ} \mathrm{C}$ as glycerol stocks for further analysis.

\section{Evaluation of probiotic properties}

All of the experiments were carried out in triplicate.

\section{Acid and bile tolerances}

The acid tolerance and bile tolerance tests of LAB isolates were carried out as described by Abushelaibi et al. (2017) and Bonatsou et al. (2018), respectively.

\section{Auto-aggregation, hydrophobicity, hemolytic, and antibacterial activity}

The LAB isolates were tested for auto-aggregation, cell hydrophobicity, and hemolytic and antibacterial activities according to the modified method described by Angmo et al. (2016). Auto-aggregation percentage was calculated using the formula $\left(1-A_{t} / A_{0}\right) \times 100$, where $A_{t}$ and $A_{0}$ represented the absorbance at time $t$ and $t=0$, respectively. N-hexadecane and xylene were employed in this study to evaluate cell hydrophobicity. Only $\gamma$-hemolytic LAB isolates were selected as potential probiotics for further analysis while others were discarded. The supernatants of 18-20-h-old LAB cells were tested against strains such as B. cereus, E. coli, S. aureus, Salmonella spp., Pseudomonas spp., and L. monocytogenes.

\section{Antibiotic susceptibility}

Antibiotic resistance of the isolates was performed according to the method of Das et al. (2016). The following antibiotic discs: penicillin G (10 units), gentamicin $(30 \mu \mathrm{g})$, quinupristin/dalfopristin $(15 \mu \mathrm{g})$, erythromycin $(15 \mu \mathrm{g})$, erythromycin $(15 \mu \mathrm{g})$, streptomycin $(10 \mu \mathrm{g})$, tetracycline $(30 \mu \mathrm{g})$, chloramphenicol $(30 \mu \mathrm{g})$, ciprofloxacin $(5 \mu \mathrm{g})$, and ampicillin $(10 \mu \mathrm{g})$ were used and the resulting zone of inhibition $(\mathrm{mm})$ was measured after incubation for $24 \mathrm{~h}$ at $37{ }^{\circ} \mathrm{C}$.

\section{Lysozyme tolerance and heat resistance}

$\mathrm{LAB}$ isolates were tested for lysozyme tolerance by incubation with the enzyme at $30{ }^{\circ} \mathrm{C}$ for $3 \mathrm{~h}$ and heat resistance at $60^{\circ} \mathrm{C}$ for $5 \mathrm{~min}$ according to the modified method described by Abushelaibi et al. (2017). 


\section{Exopolysaccharide production, $\beta$-galactosidase activity, and cholesterol removal}

Exopolysaccharide production, $\beta$-galactosidase activity, and cholesterol removal of pure $\mathrm{LAB}$ isolates were determined in accordance with the method of Abushelaibi et al. (2017).

\section{Identification of the finally selected isolates by $16 \mathrm{~S}$ rRNA sequencing}

$16 S r R N A$ sequences of the selected isolates were amplified by PCR using 27F (5'-AGAGTTTGATCCTGGCTCAG-3') and 1492R (5'-CGGTTACCTTGTTACGACTT-3') primers (Altschul et al. 1997). PCR products were sequenced by Inqaba Biotech, South Africa. The resulting sequences were assembled and edited with software BioEdit 7.2.5. Basic Local Alignment Search Tool (BLAST; http://blast.ncbi.nlm. nih.gov/Blast. cgi) was used to compare the consensus sequences with those deposited in the GenBank DNA database. A phylogenetic tree based on $16 S r R N A$ genes was constructed to determine the closest bacterial species by the neighbor joining method (Saitou and Nei 1987), using MEGA7 (Kumar et al. 2016). Sequence divergence among LAB isolates were quantified using the Maximum Composite Likelihood method (Tamura et al. 2004).

\section{Antioxidant activity of whey from milk fermented with sequenced isolates}

Each sequenced isolate was employed to ferment skimmed milk for $24 \mathrm{~h}$ at $37^{\circ} \mathrm{C}$. However, the radical scavenging screening activity using 2,2-diphenyl-1-picrylhydrazyl (DPPH) and plasma lipid peroxidation of whey fractions were carried out only on selected isolates with higher DPPH radical activities (\%), according to the modified method of Osuntoki and Korie (2010).

\section{Statistical analysis}

Data were statistically analyzed with the SPSS 22.0 version (IBM, New York, USA) and subjected to analysis of variance. Tukey's test was used to separate the differences between the means $(p \leq 0.05)$ and Pearson's correlation coefficients were determined to evaluate relationships between radical scavenging activity and lipid peroxidation inhibition.

\section{Results and discussion}

\section{Isolation, distribution, and physiological properties of LAB isolates}

Although LAB have been reported in OSL (Okeke et al. 2015), the properties and health implications have not been fully reported. Out of 64 samples of fermented OSL and LJOSL, 1388 colonies exhibiting morphological characteristics of LAB were isolated (see supplementary data A1). Generally, presumptive LAB counts (log CFU/ml) progressively increased between 0 and $48 \mathrm{~h}$ of fermentation in the steep liquors. In addition, OSL had higher LAB counts than LJOSL. As shown in Table 1, presumptive LAB counts at 0 and $24 \mathrm{~h}$ were higher and significantly different $(p \leq 0.05)$ in maize and combined cereal steep liquors at 5.09 and $5.02 \log$ CFU/ml and 7.55 and $7.65 \log$ CFU $/ \mathrm{ml}$ respectively. At $48 \mathrm{~h}, \mathrm{LAB}$ counts ranged between 7.26 and 7.73 $\log \mathrm{CFU} / \mathrm{ml}$ in millet steep liquor (MSL) and combined cereal steep liquor. At $72 \mathrm{~h}$, LAB counts reduced in all steep liquors, except in MSL (7.72 log CFU/ml). The occurrence of LAB at the onset of fermentation in all OSL has been reported by other authors (Ijabadeniyi 2007; Okeke et al. 2015; Ekwem and Okolo 2017), suggesting that fermentation commenced during steeping cereal, prior to grinding. Furthermore, the slow but gradual progression of LAB population in millet steep liquor and the gradual reduction of LAB in other steep liquors show
Table 1 Distribution of presumptive LAB counts (log $\mathrm{CFU} / \mathrm{ml}$ ) isolated from different ogi steep liquor and lemon juiceogi steep liquor

\begin{tabular}{lllll}
\hline Type of ogi steep liquor & \multicolumn{4}{l}{ LAB counts $(\log$ CFU/ml)/fermentation time } \\
\cline { 2 - 5 } & $0 \mathrm{~h}$ & $24 \mathrm{~h}$ & $48 \mathrm{~h}$ & $72 \mathrm{~h}$ \\
\hline White maize steep liquor & $5.09 \pm 0.07^{\mathrm{c}}$ & $7.55 \pm 0.03^{\mathrm{c}}$ & $7.68 \pm 0.01^{\mathrm{b}}$ & $7.48 \pm 0.03^{\mathrm{b}}$ \\
White maize steep liquor+ lemon juice & $4.00 \pm 0.00^{\mathrm{a}}$ & $7.27 \pm 0.01^{\mathrm{b}}$ & $7.41 \pm 0.04^{\mathrm{a}}$ & $7.30 \pm 0.02^{\mathrm{b}}$ \\
White sorghum steep liquor & $4.77 \pm 0.10^{\mathrm{b}}$ & $7.24 \pm 0.05^{\mathrm{b}}$ & $7.57 \pm 0.05^{\mathrm{b}}$ & $7.37 \pm 0.04^{\mathrm{b}}$ \\
White sorghum steep liquor+ lemon juice & $4.15 \pm 0.21^{\mathrm{a}}$ & $6.90 \pm 0.08^{\mathrm{a}}$ & $7.28 \pm 0.06^{\mathrm{a}}$ & $6.69 \pm 0.30^{\mathrm{a}}$ \\
Millet steep liquor & $4.69 \pm 0.12^{\mathrm{b}}$ & $7.33 \pm 0.04^{\mathrm{b}}$ & $7.26 \pm 0.17^{\mathrm{a}}$ & $7.72 \pm 0.03^{\mathrm{c}}$ \\
Millet steep liquor+ lemon juice & $4.59 \pm 0.16^{\mathrm{b}}$ & $7.49 \pm 0.06^{\mathrm{b}}$ & $7.52 \pm 0.06^{\mathrm{b}}$ & $7.20 \pm 0.04^{\mathrm{b}}$ \\
Combined cereal steep liquor & $5.02 \pm 0.09^{\mathrm{c}}$ & $7.65 \pm 0.03^{\mathrm{c}}$ & $7.73 \pm 0.05^{\mathrm{b}}$ & $7.45 \pm 0.02^{\mathrm{b}}$ \\
Combined cereal steep liquor+ lemon juice & $4.60 \pm 0.00^{\mathrm{b}}$ & $7.28 \pm 0.06^{\mathrm{b}}$ & $7.53 \pm 0.05^{\mathrm{b}}$ & $6.84 \pm 0.09^{\mathrm{a}}$ \\
\hline
\end{tabular}

Values represented as mean $\pm \mathrm{SD}$; for each column, different subscripts indicate that the values are significantly different at $p<0.05$, as measured by Tukey's test 


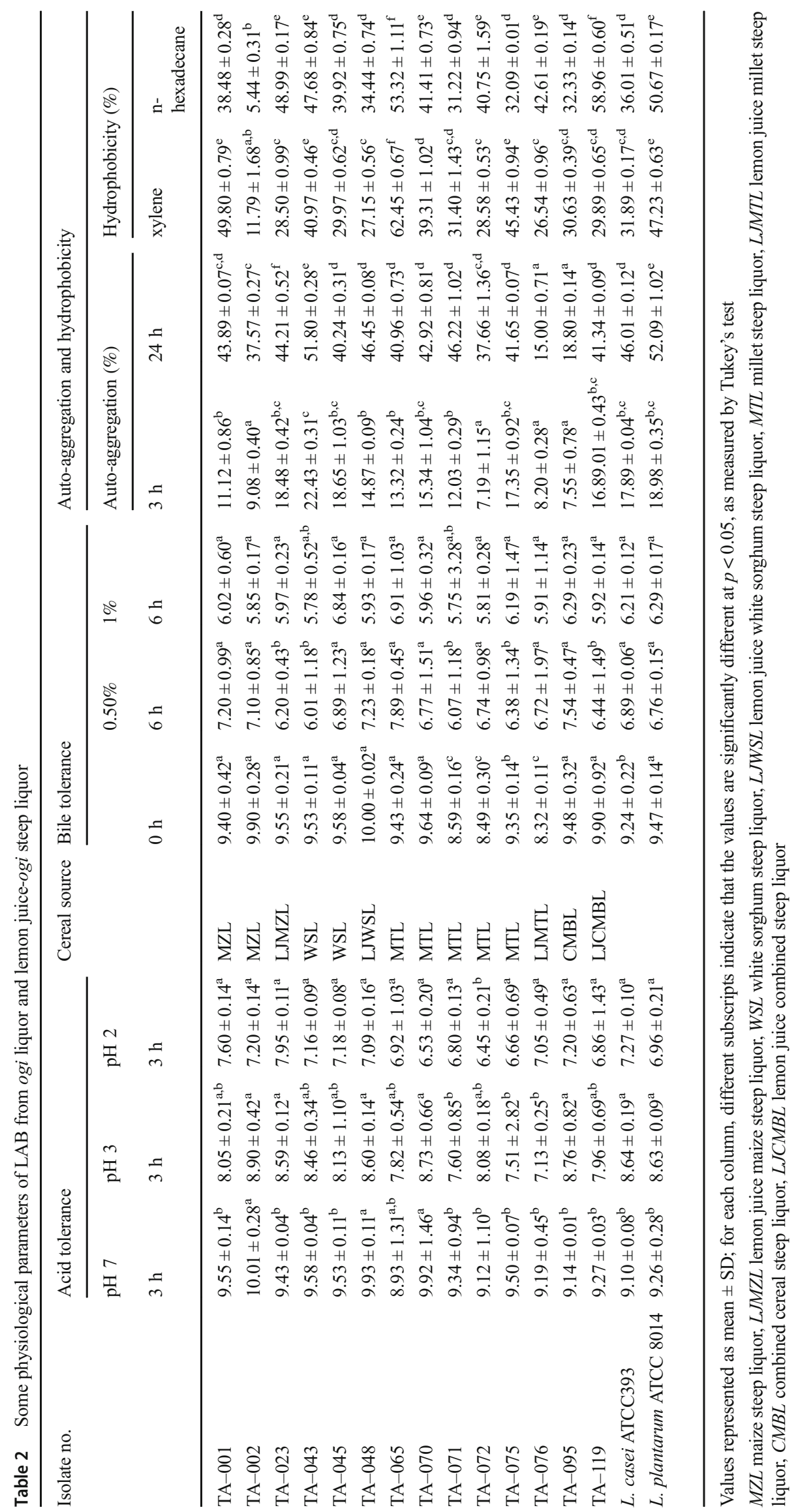


the competing influence of other microorganisms (Ekwem and Okolo 2017). However, LJOSL displayed a lower number of colonies throughout the fermentation period. This may be due to the natural antimicrobial properties of lemon, which some LAB probably could not withstand (Dhanavade et al. 2011).

One hundred and twenty isolates were randomly selected (see supplementary data A1) to determine physiological properties of LAB. All isolates were found to be Gram-positive and catalase-negative, and they grew at different temperatures $\left(15,37,45^{\circ} \mathrm{C}\right)$ and $\mathrm{NaCl}$ concentrations. All of the isolates hydrolyzed arginine and showed diversity in their fermenting ability toward different sugars.

\section{Acid and bile tolerance, auto-aggregation, hydrophobicity, and hemolytic activity}

The 120 isolates were exposed to simulated in vitro gastric juice and bile. The tolerances of some isolates were significantly reduced while there was little or no impact on the viability of most isolates at $\mathrm{pH} 3$ and $0.5 \%$ bile (see supplementary data A2). However, at $\mathrm{pH} 2$ and $1 \%$ bile, each of these isolates demonstrated progressive reduction, though 14 LAB isolates did not significantly differ $(p<0.05)$ from L. casei ATCC 393 and L. plantarum ATCC 8014. The acid and bile profile of 14 LAB is shown in Table 2. For a microorganism to be considered as potential probiotic LAB, it must withstand the hostile conditions of the human gastrointestinal tract and successively colonize it both actively and viably, by demonstrating resistance to acid and bile. The significant decrease in the survival rate at $\mathrm{pH} 2$ and in $1 \%$ bile is in accordance with the reports of other authors (Angmo et al. 2016; Abushelaibi et al. 2017). The acid and bile tolerance observed in LAB suggested that the tolerance of LAB to acid or bile was specific for each strain.

Percentages of auto-aggregation and cell surface hydrophobicity suggested that the responses of tested isolates vary. Autoaggregation of the $14 \mathrm{LAB}$ increased $(p<0.05)$ between 3 and $24 \mathrm{~h}$ with values ranging between $7.19-22.43 \%$ and 14.34 $46.45 \%$, respectively (Table 2). This adhesion characteristic determines its capability to colonize the intestine and prevent pathogen access by specific blockage of cell receptors (Divya et al. 2012). Furthermore, these isolates demonstrated higher hydrophobicity toward n-hexadecane than xylene. For xylene and n-hexadecane, the percentage hydrophobicity ranged between $11.79-62.45 \%$ and $5.44-58.96 \%$, respectively. The isolates that exhibited $\beta$-hemolysis (TA-002, TA-095) and $\alpha$ hemolysis (TA-023) were not studied further. The absence of hemolysis indicates that the bacteria are avirulent (Thakkar et al. 2015). The LAB isolates investigated in this study exhibited comparatively higher hydrophobicity and auto-aggregation at varying degrees as compared with previous study (Angmo et al. 2016; Shehata et al. 2016). Dhewa et al. (2010) reported wide variations in cell surface hydrophobicity of LAB isolates, with ranges between 21 and $70 \%$, indicating that higher values could be a sign of adherence to epithelial cells. However, the differences observed in this study may be attributed to the variations in hydrophilic/hydrophobic structures in the bacterial cell wall of LAB isolates (Abushelaibi et al. 2017).

\section{Antimicrobial resistance and antibiotic activity}

Table 3 shows the antimicrobial activities and antibiotic resistance of $11 \mathrm{LAB}$ isolates. Antimicrobial activities of LAB

Table 3 Antimicrobial activity against four pathogens and antibiotic-resistant toward nine different antibiotics

\begin{tabular}{|c|c|c|c|c|c|c|c|c|c|c|c|c|c|c|}
\hline Isolates & S. aureus & Salmonella spp. & E. coli & L. monocytogenes & $\mathrm{P}$ & $\mathrm{CN}$ & $\mathrm{E}$ & $\mathrm{S}$ & $\mathrm{C}$ & AMP & VA & CIP & $\mathrm{TE}$ & QD \\
\hline TA-001 & aaa & aa & a & aaa & $\mathrm{S}$ & $\mathrm{S}$ & $\mathrm{S}$ & $\mathrm{R}$ & $\mathrm{S}$ & MS & $\mathrm{R}$ & MS & $\mathrm{S}$ & $\mathrm{S}$ \\
\hline TA-043 & aaa & $\mathrm{a}$ & $\mathrm{a}$ & aa & $\mathrm{S}$ & MS & $\mathrm{S}$ & MS & S & MS & $\mathrm{R}$ & MS & $\mathrm{S}$ & $\mathrm{S}$ \\
\hline TA -045 & aa & $\mathrm{a}$ & $\mathrm{a}$ & aaa & $\mathrm{S}$ & $\mathrm{S}$ & $\mathrm{S}$ & $\mathrm{S}$ & $\mathrm{S}$ & $\mathrm{S}$ & $\mathrm{R}$ & $\mathrm{S}$ & $\mathrm{S}$ & $\mathrm{S}$ \\
\hline TA-048 & aa & $\mathrm{a}$ & aa & aа & $\mathrm{S}$ & $\mathrm{S}$ & $\mathrm{S}$ & $\mathrm{S}$ & $\mathrm{S}$ & $\mathrm{S}$ & $\mathrm{R}$ & $\mathrm{S}$ & $\mathrm{S}$ & $\mathrm{S}$ \\
\hline TA-065 & aaa & $\mathrm{a}$ & $\mathrm{a}$ & aaa & $\mathrm{S}$ & $\mathrm{S}$ & $\mathrm{S}$ & $\mathrm{S}$ & $\mathrm{S}$ & MS & $\mathrm{R}$ & MS & $\mathrm{S}$ & $\mathrm{S}$ \\
\hline TA-070 & aaa & aa & aa & aа & $\mathrm{S}$ & $\mathrm{S}$ & $\mathrm{S}$ & MS & S & MS & $\mathrm{R}$ & $\mathrm{S}$ & $\mathrm{S}$ & $\mathrm{S}$ \\
\hline TA-071 & aa & $\mathrm{a}$ & $\mathrm{a}$ & aaa & $\mathrm{S}$ & $\mathrm{S}$ & $\mathrm{S}$ & $\mathrm{S}$ & $\mathrm{S}$ & $\mathrm{S}$ & $\mathrm{R}$ & $\mathrm{S}$ & $\mathrm{S}$ & $\mathrm{S}$ \\
\hline TA-072 & aaa & $\mathrm{a}$ & $\mathrm{a}$ & aa & $\mathrm{S}$ & $\mathrm{S}$ & $\mathrm{S}$ & $\mathrm{S}$ & $\mathrm{S}$ & $\mathrm{S}$ & $\mathrm{R}$ & $\mathrm{S}$ & $\mathrm{S}$ & $\mathrm{S}$ \\
\hline TA-075 & aa & $\mathrm{a}$ & $\mathrm{a}$ & aa & $\mathrm{S}$ & $\mathrm{S}$ & $\mathrm{S}$ & $\mathrm{S}$ & $\mathrm{S}$ & $\mathrm{S}$ & $\mathrm{R}$ & $\mathrm{S}$ & $\mathrm{S}$ & $\mathrm{S}$ \\
\hline TA-076 & aaa & $\mathrm{a}$ & $\mathrm{a}$ & aa & $\mathrm{S}$ & $\mathrm{S}$ & $\mathrm{S}$ & $\mathrm{S}$ & $\mathrm{S}$ & MS & $\mathrm{R}$ & MS & S & S \\
\hline TA-119 & aa & $\mathrm{a}$ & $\mathrm{a}$ & aa & $\mathrm{S}$ & $\mathrm{S}$ & $\mathrm{S}$ & MS & S & MS & $\mathrm{R}$ & MS & $\mathrm{S}$ & $\mathrm{S}$ \\
\hline L. plantarum ATCC 8014 & aa & $\mathrm{a}$ & $\mathrm{a}$ & aa & $\mathrm{S}$ & $\mathrm{S}$ & $\mathrm{S}$ & $\mathrm{S}$ & $\mathrm{S}$ & $\mathrm{S}$ & $\mathrm{R}$ & $\mathrm{S}$ & $\mathrm{S}$ & $\mathrm{S}$ \\
\hline
\end{tabular}

$\mathrm{a}=$ inhibition zone $0.5-2.0 \mathrm{~mm}$; aa = inhibition zone $2.1-5.0 \mathrm{~mm}$; aaa = inhibition zone $>5.1-10 \mathrm{~mm} . \mathrm{P}=$ penicillin $\mathrm{G}(10$ units $)$, $\mathrm{CN}=$ gentamicin $(30 \mu \mathrm{g}), \mathrm{QD}=$ quinupristin/dalfopristin $(15 \mu \mathrm{g}), \mathrm{E}=$ erythromycin $(15 \mu \mathrm{g}), \mathrm{S}=$ streptomycin $(10 \mu \mathrm{g}), \mathrm{TET}=$ tetracycline $(30 \mu \mathrm{g}), \mathrm{C}=\mathrm{chloramphenicol}$ $(30 \mu \mathrm{g}), \mathrm{VAN}=$ vancomycin, $\mathrm{CIP}=$ ciprofloxacin $(5 \mu \mathrm{g})$, and AMP $=$ ampicillin $(10 \mu \mathrm{g})$

$R$ resistant, $M S$ moderately susceptible, $S$ sensitive 
Table 4 Heat $\left(60^{\circ} \mathrm{C} / 5 \mathrm{~min}\right)$, lysozyme resistant $(\log 10 \mathrm{CFU} / \mathrm{mL})$, and cholesterol removal $(\%)$ of LAB isolates

\begin{tabular}{|c|c|c|c|c|c|c|c|c|}
\hline \multirow[t]{2}{*}{ Isolates } & \multicolumn{3}{|l|}{ Lysozyme } & \multicolumn{2}{|c|}{ Heat resistance } & \multicolumn{3}{|c|}{ Cholesterol removal (\%) } \\
\hline & Control & $50 \mathrm{ppm}$ & $100 \mathrm{ppm}$ & $0 \min$ & $5 \mathrm{~min}$ & Oxbile & Sodium taurocholate & Cholic acid \\
\hline TA-001 & $8.94 \pm 0.69^{\mathrm{a}}$ & $7.69 \pm 0.69^{\mathrm{a}}$ & $5.60 \pm 0.54^{\mathrm{a}, \mathrm{b}}$ & $7.27 \pm 0.04^{\mathrm{a}}$ & $6.98 \pm 0.07^{\mathrm{b}}$ & $19.76 \pm 0.62^{\mathrm{c}}$ & $3.76 \pm 0.52^{\mathrm{a}}$ & $22.37 \pm 0.86^{\mathrm{c}}$ \\
\hline TA-043 & $8.89 \pm 0.79^{\mathrm{a}}$ & $7.64 \pm 0.79^{\mathrm{a}}$ & $5.06 \pm 0.22^{\mathrm{b}}$ & $7.36 \pm 0.05^{\mathrm{a}}$ & $7.15 \pm 0.04^{\mathrm{a}}$ & $32.72 \pm 1.41^{\mathrm{d}}$ & $5.87 \pm 0.20^{\mathrm{b}}$ & $33.48 \pm 0.14^{\mathrm{d}}$ \\
\hline TA-045 & $8.82 \pm 0.67^{\mathrm{a}}$ & $7.57 \pm 0.67^{\mathrm{a}}$ & $5.55 \pm 0.47^{\mathrm{a}, \mathrm{b}}$ & $7.36 \pm 0.05^{\mathrm{a}}$ & $6.49 \pm 0.15^{\mathrm{b}}$ & $6.57 \pm 0.99^{\mathrm{a}, \mathrm{b}}$ & $1.52 \pm 0.16^{\mathrm{a}}$ & $18.15 \pm 0.18^{b}$ \\
\hline TA-048 & $8.79 \pm 0.64^{\mathrm{a}}$ & $7.54 \pm 0.64^{\mathrm{a}}$ & $5.43 \pm 0.78^{\mathrm{a}, \mathrm{b}}$ & $7.38 \pm 0.01^{\mathrm{a}}$ & $6.31 \pm 0.05^{\mathrm{b}}$ & $15.69 \pm 0.6^{\mathrm{b}}$ & $4.65 \pm 0.38^{\mathrm{a}, \mathrm{b}}$ & $22.19 \pm 0.04^{\mathrm{c}}$ \\
\hline TA-065 & $8.80 \pm 0.64^{\mathrm{a}}$ & $7.55 \pm 0.64^{\mathrm{a}}$ & $5.77 \pm 0.79^{\mathrm{a}}$ & $6.84 \pm 0.03^{b}$ & $6.81 \pm 0.03^{\mathrm{b}}$ & $4.47 \pm 0.83^{\mathrm{a}}$ & $1.12 \pm 0.48^{\mathrm{a}}$ & $4.58 \pm 0.14^{\mathrm{a}}$ \\
\hline TA -070 & $8.77 \pm 0.61^{\mathrm{a}}$ & $7.52 \pm 0.61^{\mathrm{a}}$ & $5.88 \pm 0.01^{\mathrm{a}}$ & $7.32 \pm 0.01^{\mathrm{a}}$ & $7.29 \pm 0.02^{\mathrm{a}}$ & $26.67 \pm 1.64^{\mathrm{c}}$ & $6.45 \pm 0.06^{\mathrm{b}}$ & $24.61 \pm 0.40^{\mathrm{c}}$ \\
\hline TA-071 & $9.30 \pm 1.35^{\mathrm{a}}$ & $8.05 \pm 1.35^{\mathrm{a}}$ & $5.21 \pm 1.41^{\mathrm{a}, \mathrm{b}}$ & $7.39 \pm 0.03^{\mathrm{a}}$ & $7.34 \pm 0.03^{\mathrm{a}}$ & $28.57 \pm 0.78^{\mathrm{c}}$ & $7.65 \pm 0.39^{\mathrm{b}}$ & $34.68 \pm 0.73^{\mathrm{d}}$ \\
\hline TA-072 & $8.45 \pm 0.15^{\mathrm{a}}$ & $7.20 \pm 0.15^{\mathrm{a}}$ & $5.42 \pm 1.12^{\mathrm{a}, \mathrm{b}}$ & $7.32 \pm 0.02^{\mathrm{a}}$ & $7.30 \pm 0.03^{\mathrm{a}}$ & $7.67 \pm 0.96^{\mathrm{a}, \mathrm{b}}$ & $1.61 \pm 0.47^{\mathrm{a}}$ & $12.79 \pm 0.13^{\mathrm{b}}$ \\
\hline TA-075 & $8.90 \pm 0.78^{\mathrm{a}}$ & $7.65 \pm 0.78^{\mathrm{a}}$ & $4.70 \pm 0.11^{\mathrm{b}}$ & $7.35 \pm 0.06^{\mathrm{a}}$ & $5.15 \pm 0.21^{\mathrm{c}}$ & $11.06 \pm 0.75^{\mathrm{b}}$ & $0.35 \pm 0.19^{\mathrm{a}}$ & $14.71 \pm 0.15^{\mathrm{b}}$ \\
\hline TA-076 & $8.40 \pm 0.08^{\mathrm{a}}$ & $7.15 \pm 0.08^{\mathrm{a}}$ & $6.12 \pm 1.16^{\mathrm{a}}$ & $7.40 \pm 0.01^{\mathrm{a}}$ & $7.09 \pm 0.01^{\mathrm{a}}$ & $4.61 \pm 0.78^{\mathrm{a}}$ & $1.17 \pm 0.15^{\mathrm{a}}$ & $8.67 \pm 0.19^{\mathrm{a}}$ \\
\hline TA-119 & $8.76 \pm 0.56^{\mathrm{a}}$ & $7.51 \pm 0.56^{\mathrm{a}}$ & $5.49 \pm 0.54^{\mathrm{a}, \mathrm{b}}$ & $7.36 \pm 0.02^{\mathrm{a}}$ & $7.24 \pm 0.03^{\mathrm{a}}$ & $1.93 \pm 0.45^{\mathrm{a}}$ & $0.44 \pm 0.21^{\mathrm{a}}$ & $5.83 \pm 0.54^{\mathrm{a}}$ \\
\hline $\begin{array}{l}\text { L. plantarum } \\
\text { ATCC } 8014\end{array}$ & $8.86 \pm 0.70^{\mathrm{a}}$ & $7.61 \pm 0.70^{\mathrm{a}}$ & $6.41 \pm 0.75^{\mathrm{a}}$ & $7.31 \pm 0.02^{\mathrm{a}}$ & $7.01 \pm 0.01^{\mathrm{a}}$ & $21.27 \pm 0.14^{\mathrm{c}}$ & $5.30 \pm 0.08^{b}$ & $31.82 \pm 0.25^{\mathrm{c}, \mathrm{d}}$ \\
\hline
\end{tabular}

Values are mean \pm standard deviation of triplicate. Means in the same column with different lowercase letters differed significantly $(p<0.05)$

isolates ranged from small zones $(0.5 \mathrm{~mm})$ to wider zones $(>$ $10.0 \mathrm{~mm})$. All LAB strains were susceptible to erythromycin, tetracycline, chloramphenicol, and quinupristin/dalfopristin, moderately resistant to other antibiotics but highly resistant to vancomycin. Antimicrobial activity of each isolate varied against the four pathogens with the greatest efficacy against $S$. aureus (Table 3). The examination of other vital features like antimicrobial abilities and absence of antibiotic resistance is also required for the selection of a probiotic isolate, while the antimicrobial potential depicts the inhibitory potentials of harmful or pathogenic intestinal microbes by the production of organic acids from metabolites (Dhewa et al. 2010). The variation observed in the antagonistic activity of LAB against indicator strains has earlier been reported against E. coli, Salmonella, Shigella, S. aureus, E. faecalis, and B. cereus (Dhewa et al. 2010; Das et al. 2016; Shehata et al. 2016). However, LAB resistance to vancomycin has also been observed previously (Gad et al. 2014; Angmo et al. 2016; Abushelaibi et al. 2017). Vancomycin resistance of LAB isolates can be substantiated with the reports supporting the presence of intrinsic resistance mechanism toward this antibiotic family. This intrinsic resistance is usually non-transferable and possesses no risk in LAB (Jose et al. 2015).

\section{Heat resistance, lysozyme tolerance, and cholesterol removal}

Resistance to heat and impact of lysozyme on LAB isolates are presented in Table 4 . There was a decrease in the growth of all the isolates after heat treatment at $60{ }^{\circ} \mathrm{C}$ for $5 \mathrm{~min}$, but the reduction was not significant $(p<0.05)$ in most of the isolates when compared to the positive control. Most of the isolates, except isolate TA-075, exhibited $<65 \%$ heat resistance. Conversely, all of the isolates exhibited excellent resistance to $50 \mu \mathrm{g} / \mathrm{mL}$ of lysozyme, while a reduction in the growth of LAB was observed during incubation at a higher concentration of $100 \mu \mathrm{g} / \mathrm{mL}$. However, no significant difference was observed $(p<0.05)$ between all the isolates (except TA-075) and the positive control. Heat resistance observed in the LAB of this study is a desirable characteristic of any probiotic that is intended for food processing. Similar reports of heat resistant probiotic LAB from cocoa and dairy product have been described (Santos et al. 2016; Abushelaibi et al. 2017). All isolates tested positive for the polysaccharide with characteristic ropy colonies and $\beta$-galactosidase activity after incubation at $30{ }^{\circ} \mathrm{C}$ for $42 \mathrm{~h}$. The cholesterol removal percentages of the isolates are shown in Table 4. All LAB strains possessed the ability to hydrolyze all three bile salts that were investigated. The uptake of cholesterol by LAB in the medium varied depending on the bile medium. The cholesterol activity was highest in deconjugated bile (cholic acid 4.58-34.68\%), a mixture of conjugated $(97 \%)$ and deconjugated (3\%) bile (oxbile 1.93-32.72\%) and lowest in conjugated bile (sodium taurocholate $0.35-5.87 \%$ ). $\beta$-Galactosidase activity and the

Fig. 1 a Evolutionary relationships of isolated LAB sequences with the existing probiotic $16 S$ rRNA gene sequences using neighbor joining method. The evolutionary distances were computed using the Maximum Composite Likelihood method as conducted in MEGA7. The DNA sequences retrieved in this work are indicated by their isolate code and accession number. b (I) Radical scavenging activity of whey from milk fermented with sequenced Lactobacillus spp. (II) Inhibition of lipid peroxidation of whey by Lactobacillus spp. Error bar of triplicate determinations 
a

NR 113338.1 Lactobacillus plantarum NBRC 15891

TA-001 (MH719030)

TA-051 (MH771728)

82 NR 042394. 1 Lactobacillus plantarum NRRL B. 14768

NR 117813.1 Lactobacillus plantarum JCM 1149

NR 115605.1 Lactobacillus plantarum JCM 1149

36 TA-065 (MH733241)

TA-072 (MH732921)

NR 042058.1 Pediococcus pentosaceus DSM 20336

TA-043 (MH732913)

83 TA-045 (MH780139)

TA-076 (MH733244)

NR 113335.1 Lactobacillus fermentum NBRC 15885

TA.075 (MH732914)

99 NR 104927.1 Lactobacillus fermentum CIP 102980

TA-070 (MH732991)

TA-071 (MH732943)

TA-119 (MH732920)

84 NR 036924.1 Woissella cibaria II-1.59 16S

NR 076440.1 Pediococcus pentosaceus ATCC 25745

100 NR 076266.1 Lactobacillus fermentum IFO 3956

$\stackrel{5}{0.01}$

b $\rightarrow$ L. plantarum (TA-001) $\multimap$ P. pentosaceus (TA-045) $\rightarrow$ - L. plantarum (TA-051)

$\longrightarrow$ P. pentosaceus (TA-076) $\longrightarrow$ - L. plantarum (TA-065) $\longrightarrow$ L. fermentum (TA-070)

- L. fermentum $($ TA-071) $\rightarrow$ L. fermentum (TA-075) $\rightarrow$ L. plantarum ATCC 8014
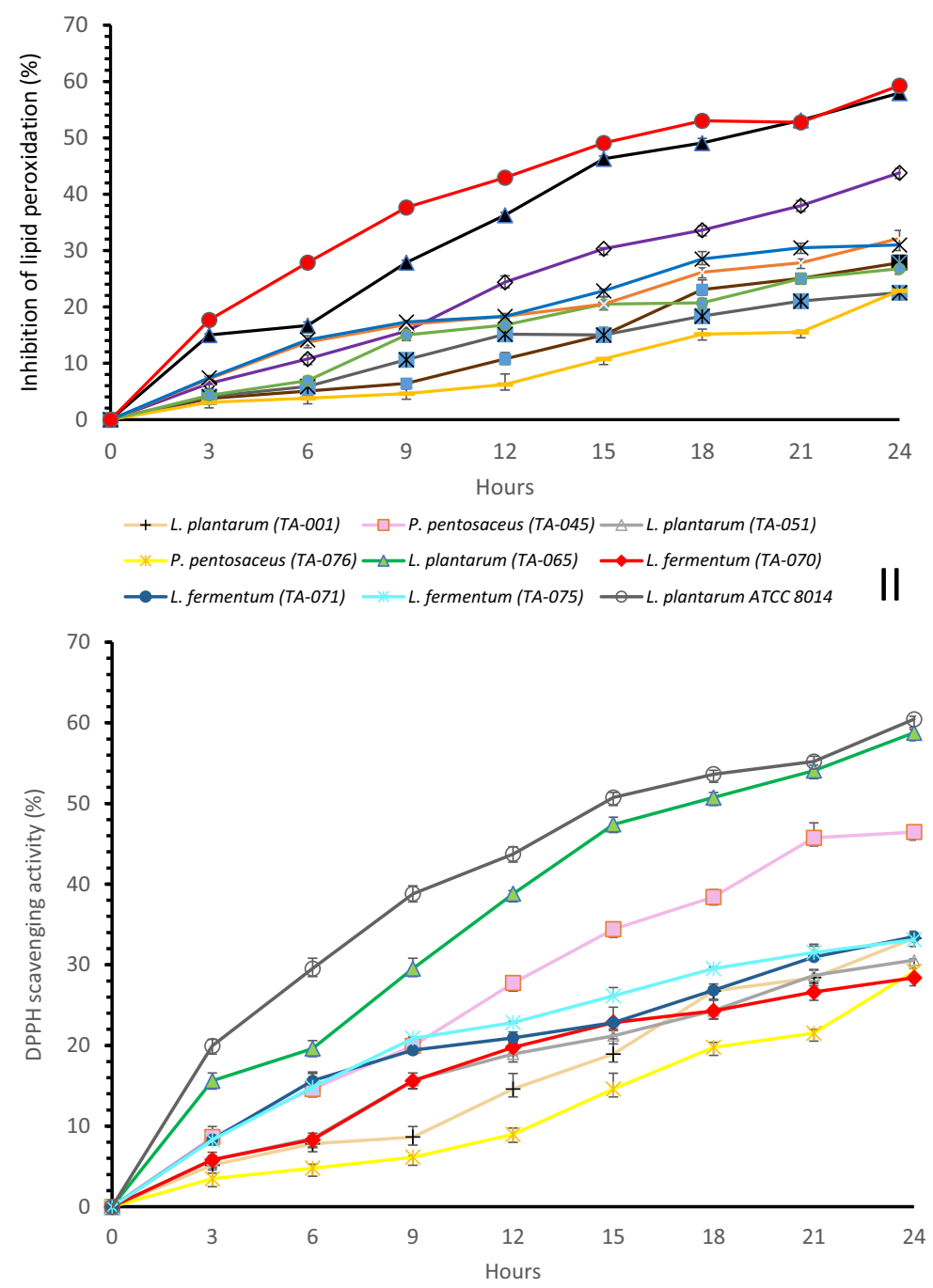
polysaccharide production observed in these isolates are good properties expected in potential probiotics.

Another important feature of probiotic is its ability to remove cholesterol. LAB hydrolyzes bile salts in human intestine thereby reducing cholesterol absorption inside intestine (Abushelaibi et al. 2017). The decrease in absorption suggests that a significant amount of cholesterol in the medium is precipitated after addition of deconjugated bile acids. Low precipitation of cholesterol was observed in the presence of conjugated bile acids sodium taurocholate. This co-precipitation effect of cholesterol and deconjugated bile acids vis-a-vis reduction in cholesterol level has been reported in some Lactobacillus spp. (Angmo et al. 2016). However, minor variation in comparison to our study may be attributed to strain and species differences.

\section{Identification of selected isolates by $16 S$ rRNA sequencing and screening of LAB isolates for DPPH activity}

Eleven potential probiotics identified by $16 S$ rRNA gene sequence showed PCR amplicons at $1500 \mathrm{bp}$. The sequence alignment was carried out using BLAST. The isolates basically clustered with specific reference probiotic strains (RPS) as shown in Fig. 1a. TA-001, TA-051, TA-065, and TA-072 had $81 \%$ similarity with $L$. plantarum RPS; TA043, TA-045, and TA-076 had $96 \%$ similarity with Pediococcus pentosaceus DSM 20336; and TA-070, TA-071, and TA-075 had 99\% similarity with $L$. fermentum RPS while TA-119 had $84 \%$ similarity with Weissella cibara II-I-59. The percentage similarity and accession numbers of analyzed isolate are in Table 5 .

Skimmed milk was initially fermented for $24 \mathrm{~h}$ with 11 sequenced $\mathrm{LAB}$ isolates that were obtained from OSL and LJOSL. The whey fractions scavenged between 1.4 and $34.43 \%$ DPPH radical (after correction for the activity of unfermented skimmed milk) as shown in Table 5. Eight strains (TA-01, 045, 051, 065, 070, 071, 075, and 076) were selected for further studies based on the results of the first stage of screening for antioxidant activity.

Fermentation of skimmed milk with LAB isolates from non-dairy sources and antioxidant activity of whey have been reported previously (Osuntoki and Korie 2010; Adesulu and Awojobi 2014), which supports the evaluation of this study. Our results show variation in antioxidant activity of each

Table 5 Identity, accession numbers, corresponding radical scavenging activity, and inhibition of lipid peroxidation of whey fractions of selected LAB

\begin{tabular}{|c|c|c|c|c|c|c|c|c|}
\hline \multirow[t]{2}{*}{ Isolate } & \multicolumn{5}{|c|}{ Identity, accession numbers, and corresponding radical scavenging activity } & \multicolumn{3}{|c|}{$\begin{array}{l}\text { Radical scavenging activity and } \\
\text { inhibition of lipid peroxidation } \\
\text { of whey after } 24 \mathrm{~h}\end{array}$} \\
\hline & Identity & $\begin{array}{l}\text { Accession } \\
\text { number }\end{array}$ & $\begin{array}{l}\text { Most closely related } \\
\text { Genbank sequence }\end{array}$ & $\begin{array}{l}\% \\
\text { similarity }\end{array}$ & $\begin{array}{l}\text { Inhibition } \\
\text { of DPPH } \\
\text { radical }(\%)\end{array}$ & $\begin{array}{l}\text { DPPH } \\
\text { scavenging } \\
\text { activity (\%) }\end{array}$ & $\begin{array}{l}\text { Lipid } \\
\text { peroxidation } \\
\text { inhibition } \\
(\%)\end{array}$ & $\begin{array}{l}\text { Pearson's } \\
\text { correlation } \\
\text { coefficient }\end{array}$ \\
\hline TA-001 & $\begin{array}{c}\text { Lactobacillus } \\
\text { plantarum }\end{array}$ & MH719030 & $\begin{array}{l}\text { L. plantarum NBRC } \\
15891\end{array}$ & 99 & $32.31 \pm 2.01$ & $33.28 \pm 1.48$ & $27.82 \pm 0.65$ & 0.97 \\
\hline TA-043 & $\begin{array}{l}\text { Pediococcus } \\
\text { pentosaceus }\end{array}$ & MH732913 & $\begin{array}{l}\text { P. pentosaceus DSM } \\
20336\end{array}$ & 99 & $9.92 \pm 0.75$ & - & - & - \\
\hline TA-045 & $\begin{array}{l}\text { Pediococcus } \\
\quad \text { pentosaceus }\end{array}$ & MH780139 & $\begin{array}{l}\text { P. pentosaceus DSM } \\
\quad 20336\end{array}$ & 99 & $45.10 \pm 0.85$ & $46.45 \pm 0.13$ & $43.78 \pm 0.70$ & 0.92 \\
\hline TA-051 & $\begin{array}{l}\text { Lactobacillus } \\
\text { plantarum }\end{array}$ & MH771728 & $\begin{array}{l}\text { L. plantarum NBRC } \\
15891\end{array}$ & 99 & $30.49 \pm 1.86$ & $30.57 \pm 0.80$ & $22.50 \pm 0.68$ & 0.92 \\
\hline TA-076 & $\begin{array}{l}\text { Pediococcus } \\
\text { pentosaceus }\end{array}$ & MH733244 & $\begin{array}{l}\text { P. pentosaceus DSM } \\
\quad 20336\end{array}$ & 99 & $29.04 \pm 0.46$ & $29.20 \pm 0.13$ & $22.88 \pm 0.78$ & 0.95 \\
\hline TA-065 & $\begin{array}{l}\text { Lactobacillus } \\
\text { plantarum }\end{array}$ & MH733241 & $\begin{array}{l}\text { L. plantarum JCM } \\
1149\end{array}$ & 99 & $58.1 \pm 1.25$ & $58.77 \pm 0.64$ & $57.94 \pm 0.39$ & 0.81 \\
\hline TA-070 & $\begin{array}{l}\text { Lactobacillus } \\
\text { fermentum }\end{array}$ & MH732991 & $\begin{array}{l}\text { L. fermentum CIP } \\
102980\end{array}$ & 99 & $28.58 \pm 0.97$ & $28.39 \pm 1.02$ & $26.76 \pm 1.21$ & 0.95 \\
\hline TA-071 & $\begin{array}{c}\text { Lactobacillus } \\
\text { fermentum }\end{array}$ & MH732943 & $\begin{array}{l}\text { L. fermentum NBRC } \\
15885\end{array}$ & 99 & $33.43 \pm 0.83$ & $33.48 \pm 0.73$ & $32.15 \pm 1.02$ & 0.83 \\
\hline TA-072 & $\begin{array}{c}\text { Lactobacillus } \\
\text { plantarum }\end{array}$ & MH732921 & $\begin{array}{l}\text { L. plantarum NBRC } \\
15891\end{array}$ & 99 & $4.45 \pm 0.47$ & - & - & - \\
\hline TA-075 & $\begin{array}{l}\text { Lactobacillus } \\
\text { fermentum }\end{array}$ & MH732914 & $\begin{array}{l}\text { L. fermentum NBRC } \\
15885\end{array}$ & 99 & $32.79 \pm 0.98$ & $33.12 \pm 0.22$ & $30.97 \pm 0.14$ & 0.80 \\
\hline TA-119 & Weissella cibaria & MH732920 & W. cibaria II-I-59 & 99 & $6.29 \pm 0.47$ & - & - & - \\
\hline $\begin{array}{l}\text { L. plantarum ATCC } \\
8014\end{array}$ & & & & & $60.18 \pm 0.56$ & $60.44 \pm 0.63$ & $59.27 \pm 0.39$ & 0.95 \\
\hline
\end{tabular}

Values are mean \pm standard deviation of triplicate. "-" indicates that the test was not carried out on the isolate 
isolate, thereby indicating strain-dependent DPPH radical scavenging activity and inhibition of plasma lipid peroxidation. This is in agreement with an earlier report (Osuntoki and Korie 2010). The antioxidant activity was found to be high in a strain of Pediococcus pentosaceus (TA-045) and L. plantarum (TA-065) while low in another strain of L. plantarum (TA-072). LAB cells were found to possess antioxidant activity in vitro. However, using the intact cells as the delivery vehicles in the gastrointestinal tract to release constituents can also be antioxidative (Pieniz et al. 2014).

\section{DPPH radical scavenging activity}

The radical scavenging activity of LAB isolates over a $24 \mathrm{~h}$ fermentation period was observed to increase from $3 \mathrm{~h}$ with the production of different peaks by these isolates (Fig. 1b). The highest DPPH and lipid peroxidation inhibitory (LPI) activity of 58.1 and $57.94 \%$, respectively, was observed in TA-065 (L. plantarum-GenBank: MH733241). Additionally, the percentage of lipid peroxidation inhibition progressed similar to the radical scavenging activity, in the whey fraction. A strong correlation was found between the DPPH and plasma lipid peroxidation activity at each interval (see supplementary data A3). The correlation coefficient at the end of $24 \mathrm{~h}$ is shown in Table 5.

The human body and food systems produce a wide variety of oxygen-centered free radicals and other reactive oxygen species. LAB possess probiotic characteristics that are continually promoted because of their desired use in the production of functional foods. Radical scavenging activity was an indicator of antioxidant activity since there were strong correlations between the DPPH scavenging activity and the inhibition of plasma lipid peroxidation. As reported in previous studies (Parvez et al. 2006; Wang et al. 2017), the probiotics in OSL and LJOSL with antioxidant potentials may have an influence on the occurrence and duration of some illnesses. They act by decreasing the proportion of unfavorable metabolites and serve as protection for healthy liver function and possibly neutralize the effects of reactive oxygen species.

\section{Conclusion}

The increased demand for products having potential health benefits has encouraged the quest to identify microorganisms from relatively unexplored edible food waste, for a potential role in probiotic research. Although a variety of probiotic $\mathrm{LAB}$ were identified in this study, their activities were found to be strain-dependent. Pediococcus pentosaceus and L. plantarum are probiotics identified in this study with high antioxidant potential, which could be used as starter cultures in functional foods. This study indicates that consumption of OSL and LJOSL may render a significant amount of dietary antioxidants. Further studies are needed for exploring the health benefit of these isolates and understanding their behavior under different fermenting conditions.

Acknowledgements The authors are grateful to Deji, Ope, Stanley, Reney, and Melvin in the Food and Enzyme laboratories, Department of Biotechnology and Food Technology, the Durban University of Technology for their technical assistance.

Funding This work is based on the research supported wholly by the National Research Foundation of South Africa (grant number: 110792).

\section{Compliance with ethical standards}

Conflict of interest The authors declare that they have no conflict of interest.

Research involving human participants and/or animals N/A. This research did not involve human participants and/or animals.

Informed consent N/A. This research did not involve human participants.

\section{References}

Abushelaibi A, Al-Mahadin S, El-Tarabily K, Shah NP, Ayyash M (2017) Characterization of potential probiotic lactic acid bacteria isolated from camel milk. LWT Food Sci Technol 79:316-325. https://doi. org/10.1016/j.lwt.2017.01.041

Adesulu AT, Awojobi KO (2014) Enhancing sustainable development through indigenous fermented food products in Nigeria. Afr J Microbiol Res 8:1338-1343. https://doi.org/10.5897/AJMR2013. 5439

Ajayeoba TA, Atanda O, Obadina A, Bankole M, Brumbley S (2016) The potential of lemon juice-ogi steep liquor mixtures in the reduction of Listeria monocytogenes contamination of ready-to-eat vegetables. LWT Food Sci Technol 74:534-541. https://doi.org/10.1016/j.lwt. 2016.08.022

Altschul SF, Madden TL, Schäffer AA, Zhang J, Zhang Z, Miller W, Lipman DJ (1997) Gapped BLAST and PSI-BLAST: a new generation of protein database search programs. Nucleic Acids Res 25: 3389-3402. https://doi.org/10.1093/nar/25.17.3389

Angmo K, Kumari AS, Bhalla TC (2016) Probiotic characterization of lactic acid bacteria isolated from fermented foods and beverage of Ladakh. LWT Food Sci Technol 66:428-435. https://doi.org/10. 1016/j.lwt.2015.10.057

Bonatsou S, Karamouza M, Zoumpopoulou G, Mavrogonatou E, Kletsas D, Papadimitriou K, Tsakalidou E, Nychas GE, Panagou EZ (2018) Evaluating the probiotic potential and technological characteristics of yeasts implicated in cv. Kalamata natural black olive fermentation. Int J Food Microbiol 271:48-59. https://doi.org/10.1016/j. ijfoodmicro.2018.02.018

Das P, Khowala S, Biswas S (2016) In vitro probiotic characterization of Lactobacillus casei isolated from marine samples. LWT Food Sci Technol 73:383-390. https://doi.org/10.1016/j.lwt.2016.06.029

Dhanavade MJ, Jalkute CB, Ghosh JS, Sonawane KD (2011) Study antimicrobial activity of lemon (Citrus lemon L.) peel extract. Br J Pharmacol Toxicol 2:119-122 
Dhewa T, Bajpai V, Saxena RK, Pant S, Mishra V (2010) Selection of lactobacillus strains as potential probiotics on basis of in vitro attributes. Int J Probiotics Prebiotics 5:45

Divya JB, Varsha KK, Nampoothiri KM (2012) Newly isolated lactic acid bacteria with probiotic features for potential application in food industry. Appl Biochem Biotechnol 167:1314-1324. https://doi.org/ 10.1007/s12010-012-9561-7

Egwim E, Amanabo M, Yahaya A, Bello M (2013) Nigerian indigenous fermented foods: processes and prospects. Mycotoxin and food safety in developing countries, Vol. 153. IntechOpen Hussaini Makun,. Doi:https://doi.org/10.5772/52877

Ekwem OH, Okolo BN (2017) Microorganisms isolated during fermentation of sorghum for production of Akamu (a Nigerian fermented gruel). Microbiol Res J Int 21:1-5. https://doi.org/10.9734/MRJ/ 2017/35601

Gad GFM, Abdel-Hamid AM, Farag ZSH (2014) Antibiotic resistance in lactic acid bacteria isolated from some pharmaceutical and dairy products. Braz J Microbiol 45:25-33. https://doi.org/10.1590/ S1517-83822014000100005

Ijabadeniyi AO (2007) Microorganisms associated with ogi traditionally produced from three varieties of maize. Res J Microbiol 2:247-253. https://doi.org/10.3923/jm.2007.247.253

Jose NM, Bunt CR, Hussain MA (2015) Implications of antibiotic resistance in probiotics. Food Rev Int 31:52-62. https://doi.org/10.1080/ 87559129.2014.961075

Kumar S, Stecher G, Tamura K (2016) MEGA7: molecular evolutionary genetics analysis version 7.0 for bigger datasets. Mol Biol Evol 33: 1870-1874. https://doi.org/10.1093/molbev/msw054

Obinna-Echem C, Kuri V, Beal J (2014) Evaluation of the microbial community, acidity and proximate composition of akamu, a fermented maize food. J Sci Food Agric 94:331-340. https://doi. org/10.1002/jsfa.6264

Ojokoh AO (2011) In vitro effect of steep water and slurry from fermented sorghum varieties on bacteria that causes diarrhea. Afr J Biotechnol 10:17712. https://doi.org/10.5897/AJB10.2249

Okeke CA, Ezekiel CN, Nwangburuka CC, Sulyok M, Ezeamagu CO, Adeleke RA, Dike SK, Krska R (2015) Bacterial diversity and mycotoxin reduction during maize fermentation (steeping) for ogi pro- duction. Front Microbiol 6. https://doi.org/10.3389/fmicb.2015. 01402

Osuntoki A, Korie I (2010) Antioxidant activity of whey from milk fermented with Lactobacillus species isolated from Nigerian fermented foods. Food Technol Biotechnol 48:505-511

Parvez S, Malik KA, Ah-Kang S, Kim HY (2006) Probiotics and their fermented food products are beneficial for health. J Appl Microbiol 100:1171-1185. https://doi.org/10.1111/j.1365-2672.2006.02963.x

Pieniz S, Andreazza R, Anghinoni T, Camargo F, Brandelli A (2014) Probiotic potential, antimicrobial and antioxidant activities of Enterococcus durans strain LAB18s. Food Control 37:251-256. https://doi.org/10.1016/j.foodcont.2013.09.055

Saitou N, Nei M (1987) The neighbor-joining method: a new method for reconstructing phylogenetic trees. Mol Biol Evol 4:406-425. https:// doi.org/10.1093/oxfordjournals.molbev.a040454

Santos TT, Ornellas RMS, Arcucio LB, Oliveira MM, Nicoli JR, Dias CV, Uetanabaro APT, Vinderola G (2016) Characterization of lactobacilli strains derived from cocoa fermentation in the south of Bahia for the development of probiotic cultures. LWT Food Sci Technol 73:259-266. https://doi.org/10.1016/j.lwt.2016.06.003

Shehata MG, El Sohaimy SA, El-Sahn MA, Youssef MM (2016) Screening of isolated potential probiotic lactic acid bacteria for cholesterol lowering property and bile salt hydrolase activity. Ann Agric Sci 61:65-75. https://doi.org/10.1016/j.aoas.2016.03.001

Tamura K, Nei M, Kumar S (2004) Prospects for inferring very large phylogenies by using the neighbor-joining method. Proc Natl Acad Sci U S A 101(30):11030-11035. https://doi.org/10.1073/ pnas.0404206101

Thakkar P, Modi HA, Prajapati JB (2015) Isolation, characterization and safety assessment of lactic acid bacterial isolates from fermented food products. Int J Curr Microbiol App Sci 4:713-725

Wang Y, Wu Y, Wang Y, Xu H, Mei X, Yu D, Wang Y, Li W (2017) Antioxidant properties of probiotic bacteria. Nutrients 9:521. https:// doi.org/10.3390/nu9050521

Publisher's note Springer Nature remains neutral with regard to jurisdictional claims in published maps and institutional affiliations. 